\title{
Cadmium uptake by marine fish larvae*
}

\author{
V. Dethlefsen ${ }^{1}, H$. von Westernhagen ${ }^{2} \&$ H. Rosenthal ${ }^{2}$ \\ 1 Institut für Küsten- und Binnenfischerei der Bundesforschungsanstalt für Fischerei; \\ Hamburg so, \\ and \\ 2 Biologische Anstalt Helgoland (Zentrale); Hamburg 50, \\ Federal Republic of Germany
}

KURZFASSUNG: Cadmiumaufnahme von marinen Fischlarven. Eier von Hering, Flunder und Hornhecht wurden in Cadmium kontaminiertem Wasser $(0,05-5,0 \mathrm{ppm})$ erbrütet und frisch geschlüptte Larven auf ihren Gehalt an Cadmium untersucht. Der Cadmiumgehalt frisch geschlüptter Larven war von den während der Erbrütung angewandten Konzentrationen abhängig. Kontamination von Flunder- und Heringslarven $(0,7-2,3 \mathrm{ng} \mathrm{Cd} / 0,1 \mathrm{mg}$ Trockengewidht) war um zwei Zehnerpotenzen höher als der Cadmiumgehalt von Hornhechtlarven, die unter den selben Bedingungen crbrütet worden waren $(0,0017-0,0185 \mathrm{ng} \mathrm{Cd} / 0,1 \mathrm{mg}$ Trokkengewicht). Der Cadmiumgehalt von Flunder- und Heringslarven stieg mit der Expositionsdauer an. Nach 8 Tagen enthielten Heringslarven $48 \mathrm{ng}$ Cd/0,1 mg Trockengewicht, während in Flunderlarven nur 5,4 ng Cd/0,1 mg Trockengewicht gemessen wurden. Der Cadmiumgehalt von Hornhechtlarven und -Juvenilen, die bei $0,05 \mathrm{ppm} \mathrm{Cd} 34$ Tage gehalten wurden, war signifikant höher als in Kontrolltieren.

\section{INTRODUCTION}

Recent investigations into cadmium as a potentially dangerous heavy metal in river sediments (KOBAYASHI, 1971; BANAT et al., 1972), estuaries (Eustace, 1974) and nearshore waters (ABDullah et al., 1972; ButTerworth et al., 1972; AbDulLAH \& ROYLE, 1974) have prompted considerable efforts to explore the toxicity of this metal and its accumulation by aquatic organisms. Numerous experiments have proved the acute and chronic toxicity of cadmium to annelids (Brown \& AHSANUlLaH, 1971), molluscs (CAlabrese et al., 1973), crustaceans (O'HARA, 1973; JoNes, 1975) and fish eggs (Rosenthal \& Sperding, 1974; Westernhagen et al., 1974, 1975; WESTERNHAGEN \& DETHLEFSEN, 1975).

High Cadmium levels in the environment are often reflected in the accumulation of this metal by organisms such as Patella vulgata (PEDEN et al., 1973), Littorina sp.

* This study has been financially supported by the Deutsche Forschungsgemeinschaft (Grant No. Ro 380/2). 
(Leatherland \& Burton, 1974), Nucella sp. (Stenner \& Nickless, 1974), and Crassostrea gigas (RATKOwSKY et al., 1973). In laboratory experiments ROSENTHAL \& Sperling (1974), Westernhagen et al. (1974), and Westernhagen \& Dethlefsen (1975) were able to show that fish eggs incubated in cadmium polluted water accumulated this metal up to a factor of 40 . Highest accumulation factors were reached shortly after exposure. During the course of incubation cadmium contents of eggs decreased continuously.

Reports on the accumulation of cadmium by fishes are not consistent. Investigations conducted by Brooks and RUMSEY (1974) and HARDISTY et al. (1974) indicate that some fishes do, at least in kidney and liver, accumulate cadmium, while PORTMANN (1972), ToppIng (1973), WINDOM et al. (1973) and EusTACE (1974) were not able to confirm accumulation of cadmium by teleosts to higher than usual concentrations.

Although for reproductive success fish larvae are an important and sensitive stage in the life cycle of fishes (SPRAGUE, 1971) there are no data available on the accumulation of cadmium by fish larvae.

This study tries to shed some light on the effects of the toxicant cadmium on newly hatched larvae and postlarvae of inshore fishes and to find out whether there do exist species specific differences in the accumulation of this metal as shown for the eggs of these species by WESTERNHAGEN et al. (1974).

\section{MATERIAL AND METHODS}

Larvae of three common inshore teleosts of the Baltic Sea, herring (Clupea barengus L.), flounder (Platichtbys flesus L.) and garpike (Belone belone L.) were subjected to cadmium contaminated water.

\section{Clupea barengus}

Eggs of Baltic spring spawning herring from Travemünde (Germany) were artificially inseminated and incubated in clean and cadmium contaminated water $(0.1,0.5,1.0,5.0 \mathrm{ppm} \mathrm{Cd})$ of $15.7,25$ and $32 \% \mathrm{~S}$ at $10^{\circ} \mathrm{C}$. Newly hatched larvae of all trials were removed and stored (dried at $80^{\circ} \mathrm{C}$ ) for later cadmium determination. For further experiments newly hatched control larvae of the $15.7 \%$ trial were transferred into $1000 \mathrm{ml}$ jars (100 specimens/jar) containing clean and cadmium contaminated seawater of $15.8 \% \mathrm{~S}$. Cadmium concentrations employed were: 0.01 , $0.05,0.1,0.5,1.0,2.0,3.0$ and $4.0 \mathrm{ppm}$. Water was exchanged every second day. The jars were not aerated. The larvae were not fed throughout the entire experiment.

$$
\text { Platichtbys flesus }
$$

Eggs of live Baltic flounder of the Fehmarn Belt were artificially inseminated in uncontaminated sea water of $16,25,32$ and $42 \% \mathrm{~S}$ at $5^{\circ} \mathrm{C}$, and incubated in $800 \mathrm{ml}$ 
jars containing seawater and test solutions of $0.1,0.5,1.0,2.0,3.0$ and $5.0 \mathrm{ppm}$ cadmium. The larvae were kept at $5^{\circ} \mathrm{C}$ without aeration and food for two weeks.

\section{Belonebelone}

Eggs of freshly caught Baltic garpike from Travemünde (Germany) were artificially inseminated in seawater $\left(15,25\right.$ and $35 \%$ at $14.7^{\circ} \mathrm{C}$. The eggs then were incubated at $15^{\circ} \mathrm{C}$ in $800 \mathrm{ml}$ jars containing uncontaminated seawater of the above salinities and test solutions of $0.05,0.1,0.5,1.0,2.0$ and $5.0 \mathrm{ppm} \mathrm{Cd}^{2+}$ using $\mathrm{CdCl}_{2}$ as toxicant. Newly hatched larvae were transferred into uncontaminated seawater where they were fed and reared until they reached $60 \mathrm{~mm}$ in length. Other newly hatched larvae were kept in 501 basins containing natural and contaminated $(0.05$

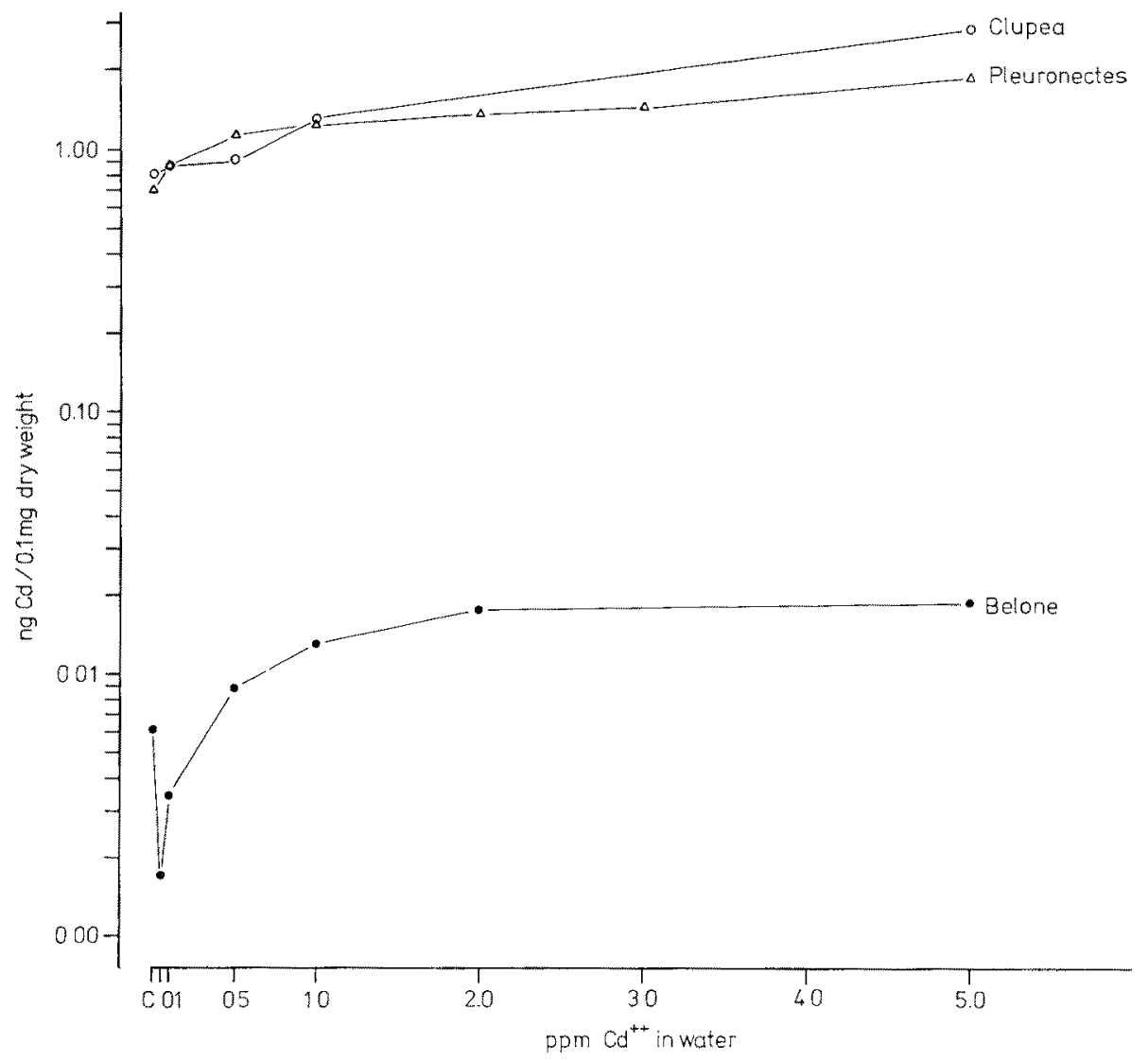

Fig. 1: Cadmium contents in newly hatched herring, flounder and garpike larvae incubated at different cadmium concentrations. Combined data from $15 \%(16 \%), 25 \%$ and $32 \%$ $(35 \% 00) \mathrm{S}$ experiments 
ppm Cd) seawater of $32 \% \mathrm{~S}$ and $23^{\circ} \mathrm{C}$ and reared for 34 days. Water in the two basins was exchanged every 5 days.

Cadmium determination in all experiments was accomplished by means of flameless atomic absorption spectrophotometry using a Perkin Elmer Type 300 equipped with an electrodeless discharge lamp. For determination of cadmium, water samples and larval samples were treated as described by Westernhagen and Dethlefsen (1975).

\section{RESULTS}

In Figure 1 cadmium concentrations found in newly hatched larvae are depicted for all three species. Concentrations found in garpike larvae were of two orders of magnitude lower than those for flounder and herring larvae incubated at the same contamination levels. Maximum values at $5.0 \mathrm{ppm}$ in garpike larvae only reached

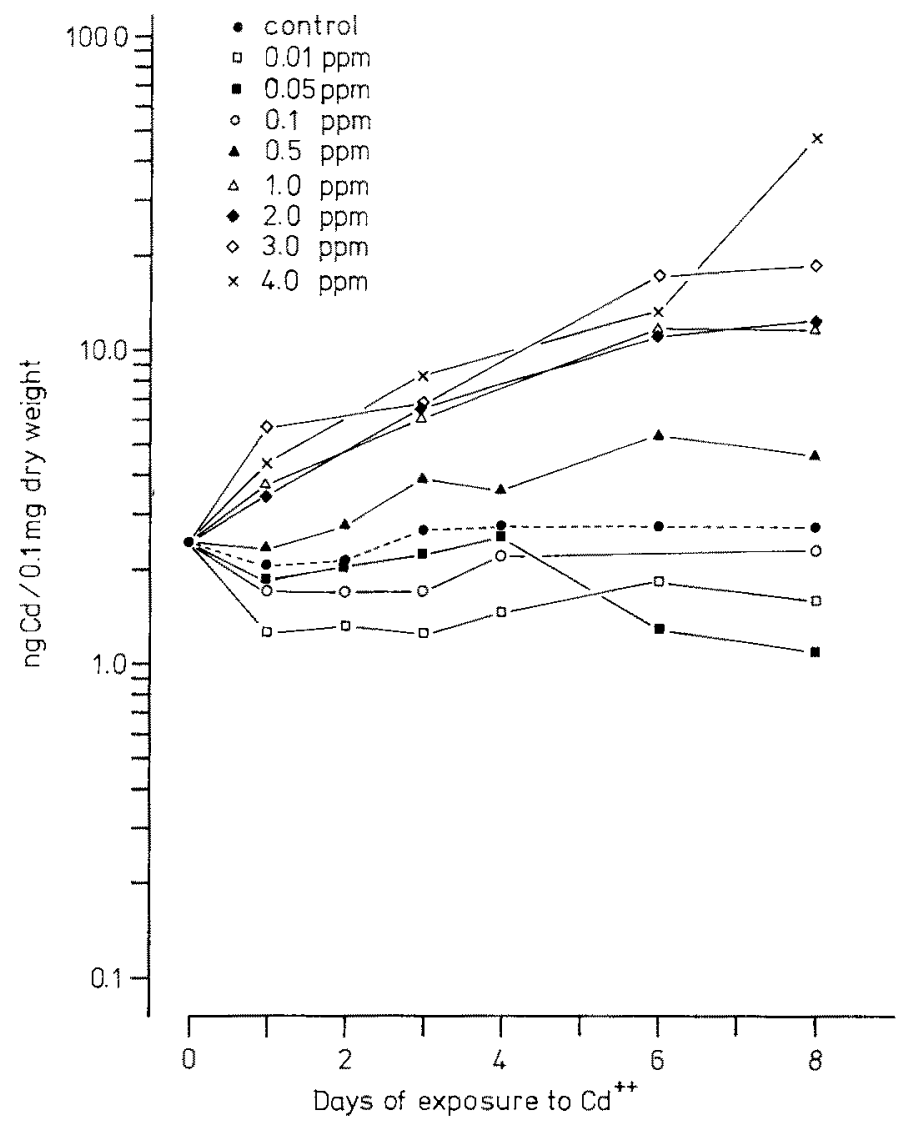

Fig. 2: Cadmium uptake by newly hatched herring larvae exposed to different cadmium concentrations at $10^{\circ} \mathrm{C}$ and $16 \% \mathrm{~S}$ 
$0.018 \mathrm{ng} \mathrm{Cd} / 0.1 \mathrm{mg}$ larval dry weight, while flounder and herring larvae at $5.0 \mathrm{ppm}$ contained 1.9 and $2.3 \mathrm{ng} \mathrm{Cd} / 0.1 \mathrm{mg}$ dry weight.

Figure 2 presents cadmium uptake of newly hatched herring larvae incubated in uncontaminated water and subjected to different cadmium concentrations after hatching. From 0.01 to $0.1 \mathrm{ppm}$ uptake over the 8 -day period did not exceed values derived from the control trials. It was only at ambient cadmium concentrations of $0.5 \mathrm{ppm}$ and

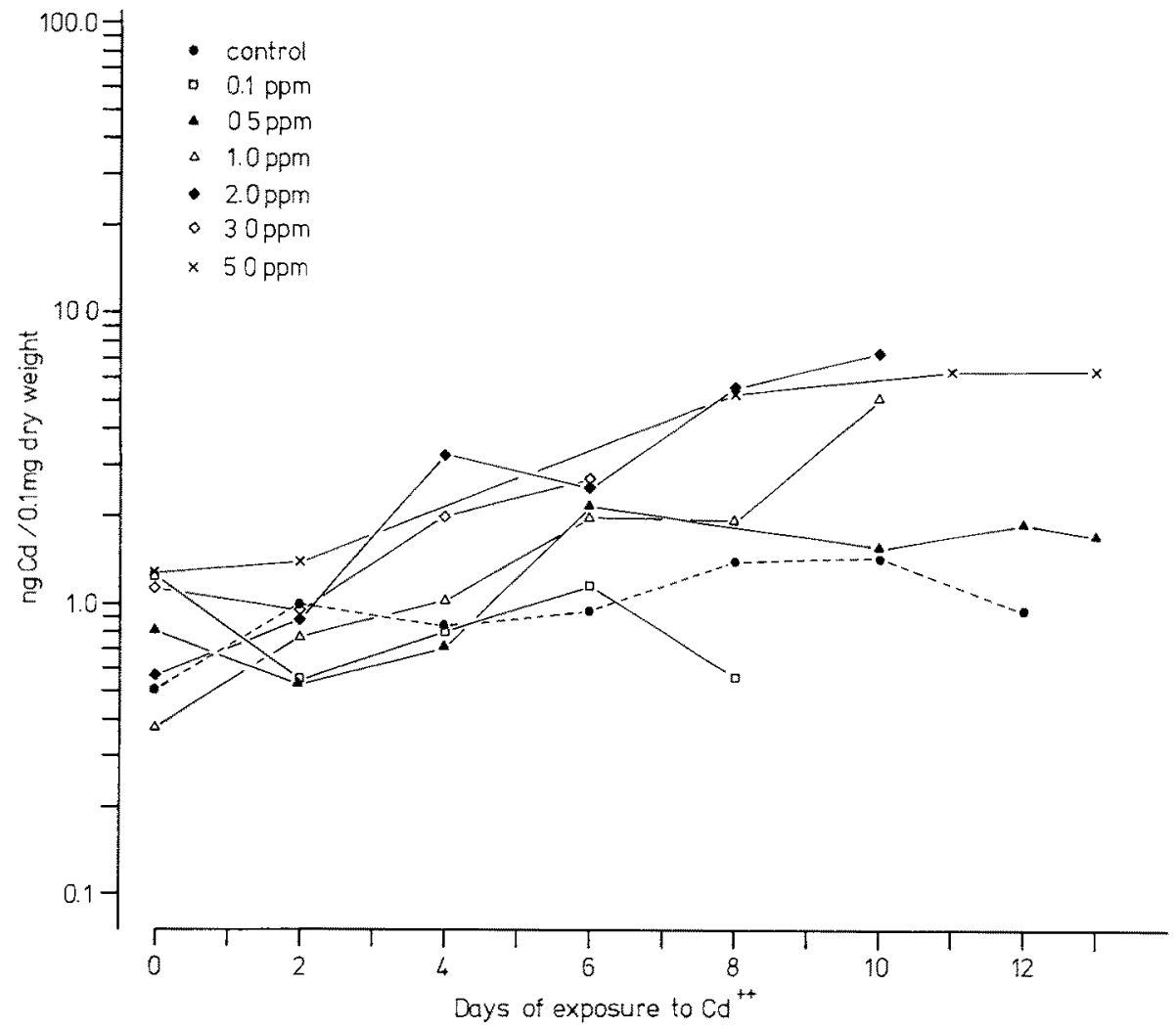

Fig. 3: Cadmium uptake by newly hatched flounder larvae incubated at different cadmium concentrations and exposed to the respective concentrations after hatching at $5^{\circ} \mathrm{C}$ and $42 \% \mathrm{~S}$

more that metal concentrations in larvae showed clear differences to controls, at 4.0 ppm reaching 15 times the concentrations ( $48 \mathrm{ng} \mathrm{Cd} / 0.1 \mathrm{mg}$ dry weight) recorded from control individuals during the study period. Larval survival during the 8 -day period was lowest with $57 \%$ in the $4.0 \mathrm{ppm}$ trial increasing over $64 \%(3.0 \mathrm{ppm}), 72 \%$ $(2.0 \mathrm{ppm})$ and $73 \%(1.0 \mathrm{ppm})$ to $84 \%$ in the controls. There were pronounced reductions in swimming activities exhibited by larvae kept at cadmium concentrations ranging from 2.0 to $4.0 \mathrm{ppm}$.

Figure 3 shows cadmium uptake of newly hatched flounder larvae incubated in cadmium contaminated water and exposed to different cadmium concentrations imme- 
diately after hatching. Concentrations of $0.5 \mathrm{ppm}$ and higher caused accumulation of cadmium with exposure time. The same trend is noticeable in Figure 4, where mean values ( $\mathrm{ng} \mathrm{Cd} / 0.1 \mathrm{mg}$ larval dry weight) for the combined data derived from 16, 25 and $32 \% \mathrm{~S}$ are presented. There was a marked tendency only in the higher cadmium concentrations of 1.0 and $5.0 \mathrm{ppm}$ towards increasing larval cadmium contamination with exposure time. Garpike larvae and juveniles also displayed accumulation of

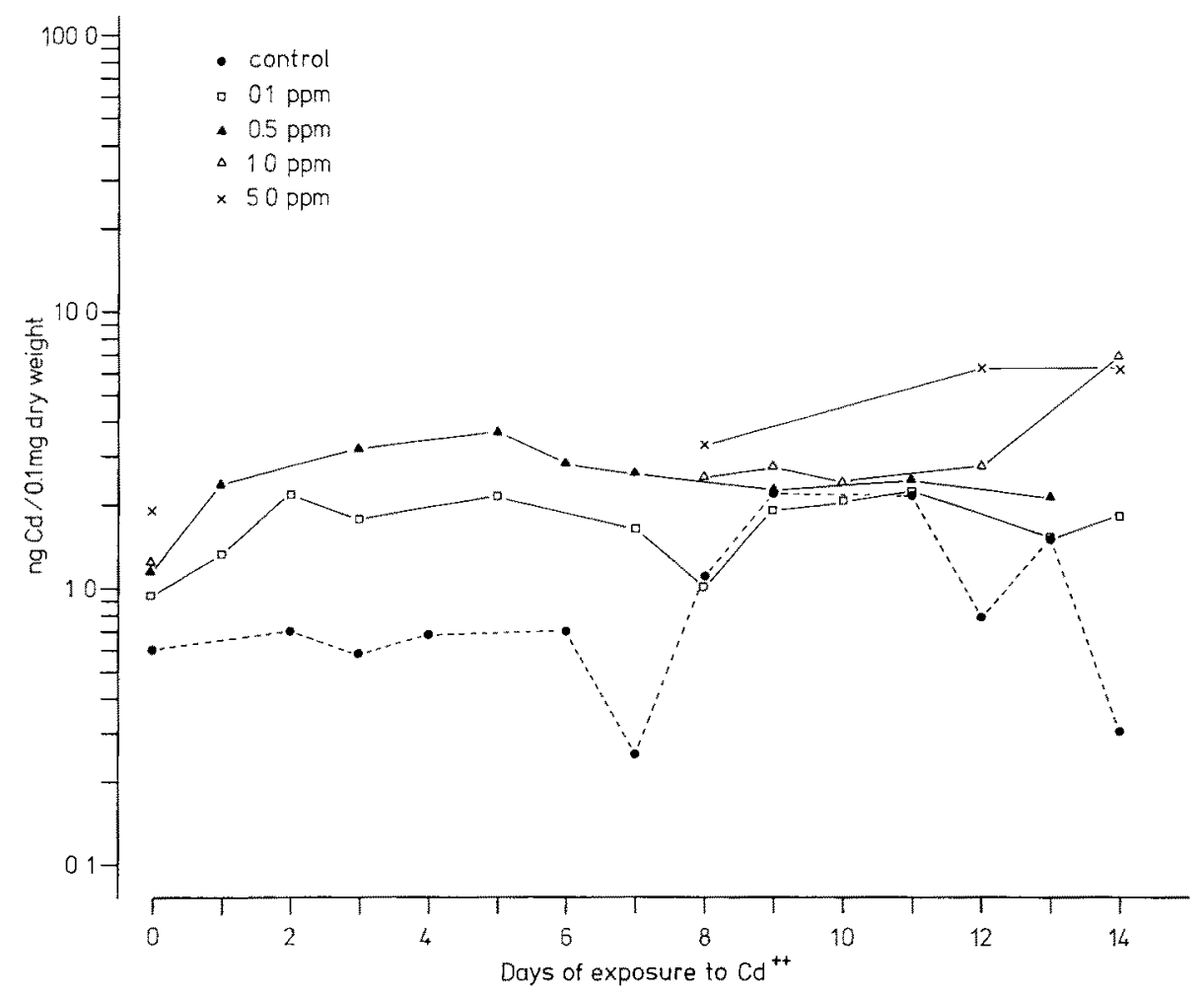

Fig. 4: Cadmium uptake by newly hatched flounder larvae incubated at different cadmium concentrations and exposed to the respective concentrations after hatching at $5^{\circ} \mathrm{C}$. Combined. data from $16 \%, 25 \%$ and $32 \% \mathrm{~S}$

cadmium during a prolonged period of exposure to $0.05 \mathrm{ppm}$ cadmium. After 34 days the differences in mean cadmium contents of control and continuously exposed specimens (final total length, $60 \mathrm{~mm}$ ) were highly significant (control: $\bar{x}=0.00260 \mathrm{ng} \mathrm{Cd}$ i $0.1 \mathrm{mg}$ dry wt; $0.05: \overline{\mathrm{x}}=0.00971 \mathrm{ng} \mathrm{Cd} / 0.1 \mathrm{mg}$ dry wt; $\mathrm{t}_{0.05}=3.82$ ).

We were not able to prove any detrimental after effects of cadmium on garpike larvae incubated in concentrations of up to $2.0 \mathrm{ppm}$. After transfer to unpolluted water newly hatched larvae of contamination levels from 0.05 to $2.0 \mathrm{ppm}$ cadmium fed and grew over a period of more than 30 days, when the experiment was terminated. Initial body curvature of larvae hatched at $2.0 \mathrm{ppm}$ disappeared after about 

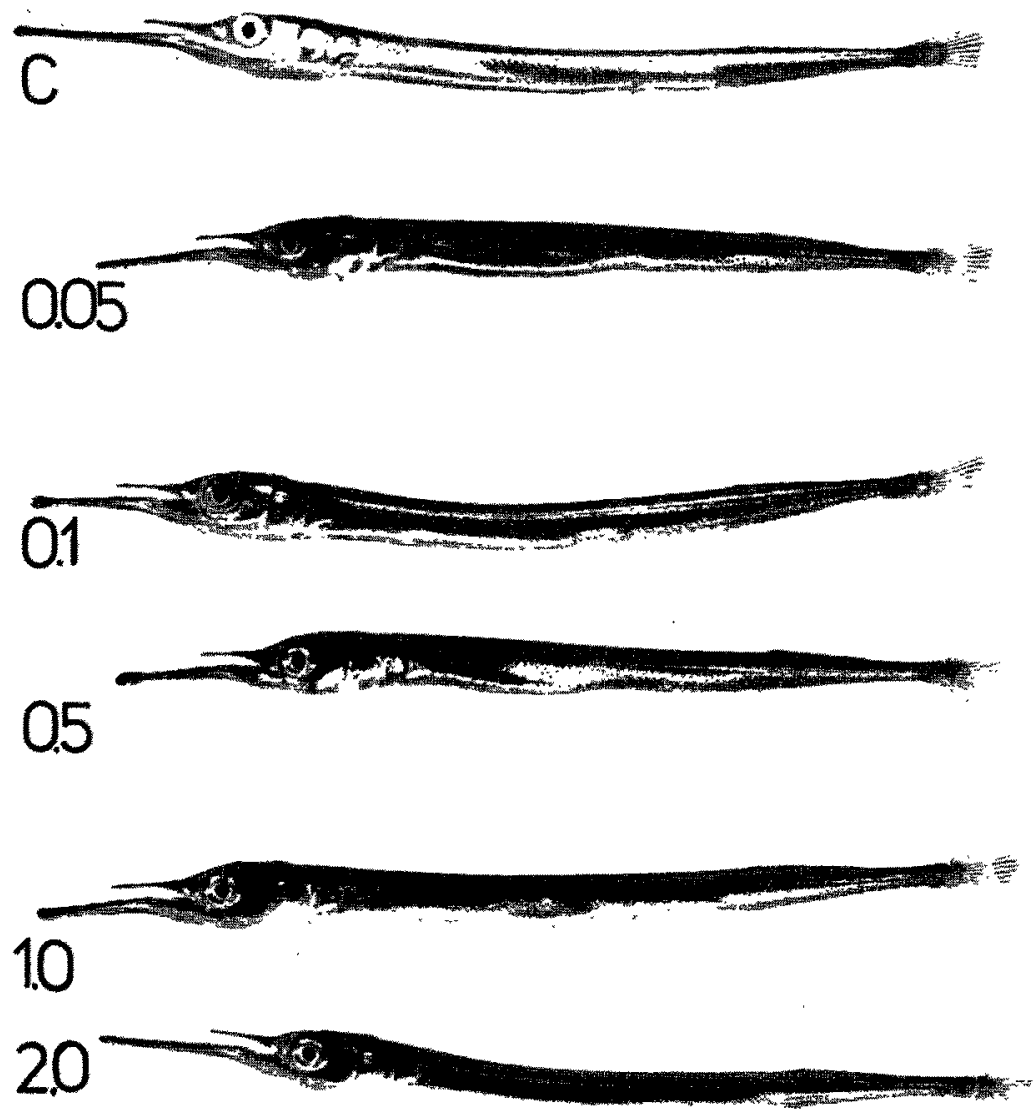

Fig. 5: Juvenile garpike incubated at cadmium concentrations from 0.05 to $2.0 \mathrm{ppm}$ and reared in cadmium-free water for 34 days at room temperature. C: controls

10 days rearing and the young garpikes at the end of the experiment attained a length between 55 and $62 \mathrm{~mm}$. All the specimens appeared normal and in good condition (Fig. 5). Most probably the recovery of the initially bent larvae could be contributed to the high vitality of Belone larvae, since a cadmium clearance would take longer, as described by Greig et al. (1974), who showed that cadmium contaminated Tautogolabrus adspersus after being reared in clean seawater for one month did not exhibit substantial reductions in cadmium residues of liver and flesh.

\section{DISCUSSION}

Values of cadmium contamination of newly hatched larvae of flounder and herring incubated in polluted water (Fig. 1) range from 0.7 to $2.3 \mathrm{ng} \mathrm{Cd} / 0.1 \mathrm{mg} \mathrm{dry}$ 
weight and are in good agreement with the data given by Rosentril \& SPERLING (1974) who found about $1.7 \mathrm{ng}$ per newly hatched herring larva incubated at $5.0 \mathrm{ppm}$ $\mathrm{Cd}$. Although the egg membrane as described by Rosenthal \& SPERLing (1974) and WESTERNHAGEN et al. (1974) acts as a "protecting barrier" that shields the developing embryo against the toxic effects of cadmium, measureable amounts of this metal do penetrate the chorion, which is reflected by the degree of contamination of newly hatched larvae. With increasing cadmium concentration of the incubating medium the cadmium contents of larvae rose. Larvae incubated at $5.0 \mathrm{ppm}$ contained about thrice the amounts of the metal found in control specimens. Why contamination levels of newly hatched garpike larvae were of two orders of magnitude lower than found in herring and flounder larvae is not clear. It might be possible that the chorion of Belone eggs is especially efficient in retaining cadmium. We are as yet not certain, but this assumption is supported by the fact that in the high contamination levels (2.0-5.0 ppm) a yellow precipitate developed on the eggs' surface (Fig. 6). This was especially evident where the adhesive filaments had been torn off the chorion surface and yellow flakes (possibly CdS ?) could be scraped off. Analysis of these flakes showed that they were extremely rich in cadmium.

The experiments demonstrate that fish larvae exposed to cadmium contaminated water display reactions differing from those of developing eggs of the same species. While initial cadmium concentrations reached by eggs during the first $24 \mathrm{~h}$ would usually decrease during incubation, cadmium content of exposed larvae increased with time. Herring larvae exposed to $4.0 \mathrm{ppm}$ for 8 days accumulated up to $48 \mathrm{ng} \mathrm{Cd} / 0.1$ $\mathrm{mg}$ dry weight (Fig. 2). This was twice the amount of the maximum contamination level of eggs exposed to $5.0 \mathrm{ppm}$. Flounder larvae with an initial contamination level of about $1.0 \mathrm{ng} / \mathrm{Cd} 0.1 \mathrm{mg}$ dry weight accumulated up to $7.0 \mathrm{ng} \mathrm{Cd} / 0.1 \mathrm{mg} \mathrm{d}$ ry weight after 10 to 14 days exposure to $2.0 \mathrm{ppm}$ cadmium (Fig. 3 and 4), which slightly surpasses the maximum concentrations reached by eggs under the same conditions (WESTERnhagen \& DethLEFSEN, 1975). The mechanisms with which the binding of the metal to the larvae is accomplished appear to be different from those assumed to function in the reaction of egg surfaces with cadmium. In the case of metal binding to fish eggs, Rosenthal \& SperLing (1974) and Westernhagen et al. (1974) assumed the presence of a complexing agent on or in the chorion, which could account for the rapid metal uptake until a saturation level is reached, depending on the ambient cadmium concentration. The continuous increase in metal contents of larvae with exposure time indicates a mechanism suggested by Gould \& KARolus (1974) for the binding of metal in the cunner Tautogolabrus adspersus: the formation of metalprotein. In this connection it might be of interest that metal binding proteins (metallothioneins) have already successfully been isolated by Olafson \& THOMpson (1974) from the rockfish liver (Sebastodes caurinus) on administration of $\mathrm{CdCl}_{2}$.

Herring larvae in our experiments accumulated more cadmium/0.1 mg dry weight during a certain period of time than did flounder larvae (differences in holding temperatures being neglected). Species specific differences in the ability to accumulate certain metals have already been observed by Hardisty et al. (1974). In their investigations, tissues from flounders (Platichthys flesus) from the Severn estuary con- 
tained about four times less cadmium than samples taken from Liparis liparis or Pomatoschistus minutus from the same area.

There appears to occur fairly rapid time dependent uptake of cadmium by fish larvae exposed to high concentrations of this metal. Experiments conducted by GRErG et al. (1974) with Tautogolabrus adsperstus also proved rapid uptake of cadmium from

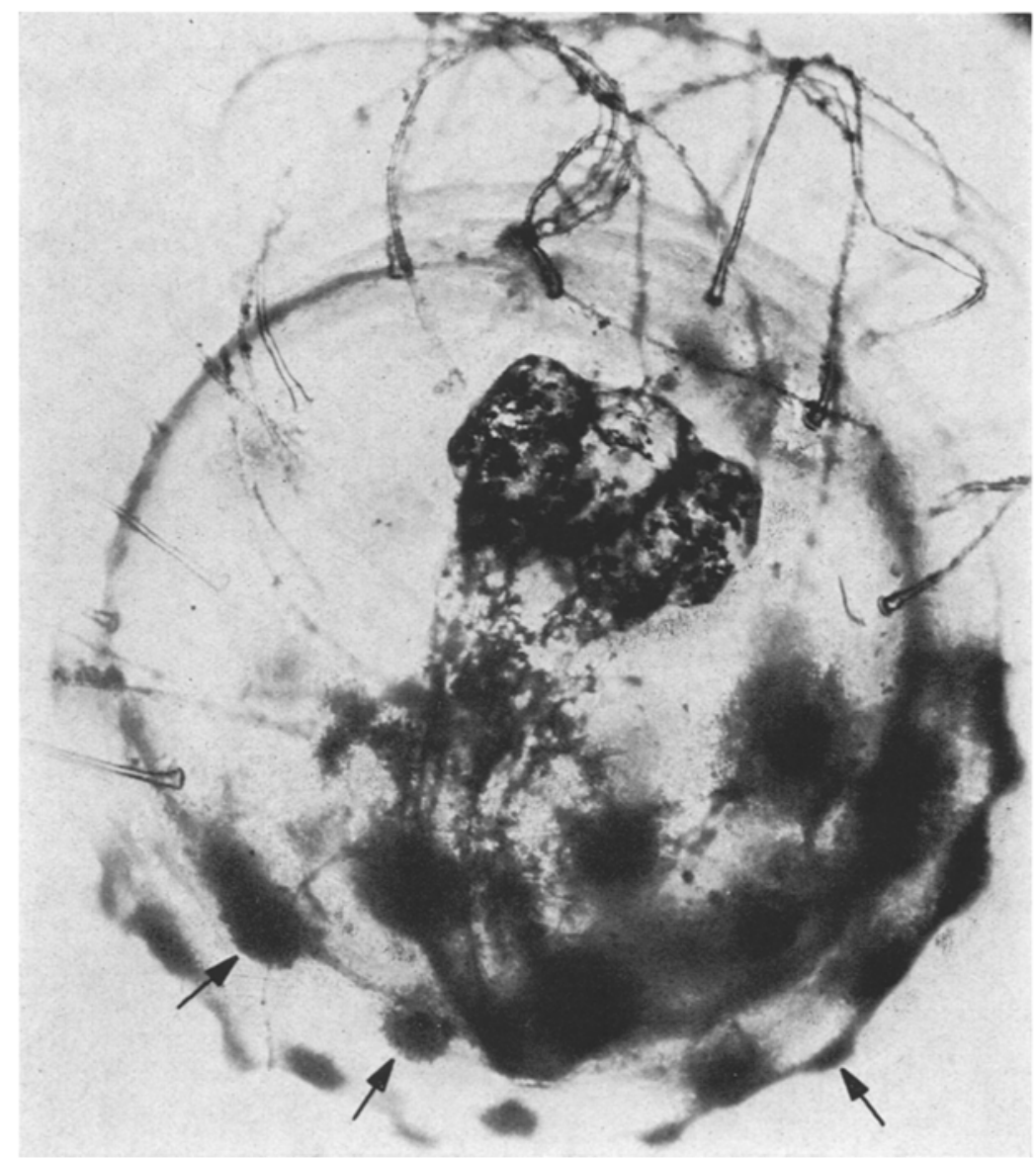

Fig. 6: Garpike egg incubated at $5.0 \mathrm{ppm}$ cadmium concentration, showing yellow flakes on chorion surface as indicated by arrows

the surrounding medium. After 4 days of exposure to $3.0 \mathrm{ppm} \mathrm{Cd}$ (as $\mathrm{CdCl}_{2}$ ), cadmium concentrations in liver tissues of experimental fish approximated $15 \mathrm{ppm}$ (wet weight basis). These values are similar to those recorded by Brooks \& Rumsey (1974) in the liver of wild catches of Polyprion oxygeneios from New Zealand, showing that in their natural habitat fishes are able to accumulate cadmium against an existing ambient concentration. Similar results have been obtained by Portmann (1972), Preston (1973) and WON (1973) who could show that cadmium concentrations in fishes were 
well above those of the surrounding water $(0.12-0.18 \mu \mathrm{g} / \mathrm{g}$ wet weight fish; $0.6-0.8$ $\mu \mathrm{g} / \mathrm{l}$ seawater $)$.

In our experiments larvae exposed to low concentrations of cadmium $(0.01,0.05$, 0.1 ; Figs. 2 and 3 ) did not show elevated metal concentrations over a short period of 8 to 14 days. Yet longer exposure of 30 days at high temperature $\left(22^{\circ} \mathrm{C}\right)$, in rearing experiments with Belone larvae and juveniles, did yield cadmium concentrations in the experimental fish 4 times higher than determined in control specimens. Also EISLER et al. (1972) were able to prove accumulation of cadmium by Fundulus at concentrations of $0.01 \mathrm{ppm}$ after 21 days of exposure.

As evident from our experiments, as of now there are no acute toxic or lethal effects on fish larvae expected to be caused by cadmium in concentrations presently found in the environment (unpolluted waters: 0.00001-0.00041 ppm, PrEsTON, 1973; polluted waters: $0.005 \mathrm{ppm}$, BUTTER wORTH et al., 1972). Yet the demonstrated ability of fish larvae to extract and accumulate cadmium from the surrounding sea water is reason enough to watch the development of heavy metal concentrations in coastal waters carefully. Further long-term experiments would have to reveal whether low cadmium concentrations $(0.00001-0.0001 \mathrm{ppm})$ would be sufficient to cause dangerously high accumulation levels in fish larvae and fry, which due to their high surface/ volume ratio are more liable to concentrate heavy metals than adult fish.

\section{SUMMARY}

1. Eggs of herring (Clupea harengus), flounder (Platichthys flesus), and garpike (Belone belone) were incubated in cadmium contaminated water $(0.05-5.0 \mathrm{ppm})$ and newly hatched larvae analyzed for cadmium contents.

2. Cadmium residues in newly hatched larvae were dependent on cadmium concentrations employed during incubation.

3. Cadmium contents of newly hatched flounder and herring larvae $(0.7-2.3 \mathrm{ng} \mathrm{Cd} /$ $0.1 \mathrm{mg}$ dry weight) were of two orders of magnitude higher than in Belone belone larvae incubated under the same conditions $(0.0017-0.0185 \mathrm{ng} \mathrm{Cd} / 0.1 \mathrm{mg} \mathrm{dry}$ weight).

4. Cadmium contents of herring and flounder larvae held in cadmium contaminated water increased with exposure time.

5. Cadmium contents of herring larvae exposed to cadmium contaminated water for 8 days were of one order of magnitude higher than contamination of flounder larvae kept under similar conditions (max. value for herring $48 \mathrm{ng} \mathrm{Cd} / 0.1 \mathrm{mg}$ dry weight; $\max$ value for flounder $5.4 \mathrm{ng} \mathrm{Cd} / 0.1 \mathrm{mg}$ dry weight).

6. Cadmium contents of Belone belone larvae and juveniles kept at $0.05 \mathrm{ppm} \mathrm{Cd}$ for 30 days were significantly higher than cadmium contamination of control specimens.

Acknowledgements. We are indebted to G. Fürstenberg, T. Hudtwalcker, J. KlinckManN, E. Ropers and G. Villa-Ruiz for expert technical assistance and M. Blake for advice on the preparation of the manuscript. 


\section{LITERATURE CITED}

Abdullah, M. J. \& Morris, A. W., 1972. Heavy metal concentration in coastal waters. Nature, Lond. 235, 158-160.

- \& Royle, L. G., 1974. A study of the dissolved and particulate trace elements in the Bristol Channel. J. mar. biol. Ass. U.K. 54, 581-597.

Banat, K., Förstner, U. \& Müller, J., 1972. Schwermetalle in Sedimenten von Donau, Rhein, Ems, Weser und Elbe im Bereich der Bundesrepublik Deutschland. Naturwissenschaften 59, 525-528.

Brooks, R. R. \& Rumsey, D. A., 1974. Heavy metals in some New Zealand commercial sea fishes. N. Z. J. mar. Freshwat. Res. 8, 155-166.

Brown, B. \& Ahsanullah, M., 1971. Effect of heavy metals on mortality and growth. Mar. Pollut. Bull. 2, 182-187.

Butterworth, J., Lester, P. \& Nickless, G., 1972. Distribution of heavy metals in the Severn estuary. Mar. Pollut. Bull. 3, 72-74.

Calabrese, A., Collier, R. S., Nelson, D. A. \& McInnes, J. R., 1973. The toxicity of heavy metals to embryos of the American oyster Crassostrea virginica. Mar. Biol. 18, 162-166.

Eisler, R., Zaroogian, G.E. \& Hennekey, R. J., 1972. Cadmium uptake by marine organisms. J. Fish. Res. Bd Can. 29, 1367-1369.

Eustace, I. J., 1974. Zinc, cadmium, copper and manganese in species of finfish and shellfish caught in the Derwent estuary, Tasmania. Aust. J. mar. Freshwat. Res. 25, 209-220.

Gourd, E. \& Karolus, J. J., 1974. Physiological response of the cunner, Tautogolabrus adspersus, to cadmium. V. Observations on the biochemistry. NOAA Tech. Rep. NMFS SSRF - 681, 21-25.

Greig, R. A., Adams, A. E. \& Nelson, B. A., 1974. Physiological response of the cunner, Tautogolabrus adspersus. II. Uptake of cadmium by organs and tissues. NOAA Tech. Rep. NMFS SSRF - 681, 5-9.

Hardisty, M. W., Huggins, R. J., KarTar, S. \& Sannsbury, M., 1974. Ecological implications of heavy metal in fish from the Severn estuary. Mar. Pollut. Bull. 5, 12-15.

JONES, M. B., 1975. Synergistic effects of salinity, temperature and heavy metals on mortality and osmoregulation in marine and estuarine isopods (Crustacea). Mar. Biol. 30, 13-20.

Kobayashi, J., 1971. Relation between the "itai-itai" disease and the pollution of river water by cadmium from a mine. Adv. Wat. Pollut. Res. 1, 1-32.

LeATHERLAND, T. M. \& BuRTON, J. D., 1974. The occurrence of some trace metals in coastal organisms with particular reference to the Solent region. J. mar. biol. Ass. U. K. 54, 457-468.

O'HARA, J., 1973. The influence of temperature and salinity on the toxicity of cadmium to the fiddler crab, Uca pugilator. Fish. Bull. 71, 149-153.

Olafson, R. W. \& Thompson, J. A. J., 1974. Isolation of heavy metal binding proteins from marine vertebrates. Mar. Biol, 28, 83-86.

Peden, J. D., Crothers, J. H., Waterfall, C. E. \& Beasley, J., 1973. Heavy metals in Somerset marine organisms. Mar. Pollut. Bull. 4, 7-9.

Portmann, J. E., 1972. The levels of certain metals in fish from coastal waters around England. Aquaculture 1, 91-96.

Preston, A., 1973. Heavy metals in British waters. Nature, Lond. 242, 95-97.

Ratkowsky, D. A., Thrower, S. J., Eustace, I. J. \& Olle, J., 1974. A numerical study of the concentration of some heavy metals in Tasmanian oysters. J. Fish. Res. Bd Can. 31, 1165-1171.

Rosenthal, H. \& SPERLing, K.-R., 1974. Effects of cadmium on development and survival of herring eggs. In: The early life history of fish. Ed. by J. H. S. BLAxTER. Springer, Berlin, 383-396.

Sprague, J. B., 1971. Measurements of pollutant toxicity to fish. III. Sublethal effects and "safe" concentration. Wat. Res. 5, 245-266.

Stenner, R. D. \& Nickless, G., 1974. Absorption of cadmium, copper and zinc by dog whelks in the Bristol Channel. Nature, Lond. 247, 198-199.

Topping, G., 1973. Heavy metals in fish from Scottish waters. Aquaculture 1, 373-377. 
Westernhagen, H. von, Rosenthal, H. \& Sperling, K.-R., 1974. Combined effects of cadmium and salinity on development and survival of herring eggs. Helgolinder wiss. Meeresunters. 26, 416-433.

- \& Dethlefsen, V., 1975. Combined effects of cadmium and salinity on development and survival of flounder eggs. J. mar. biol. Ass. U. K. 55, 945-957.

- - \& Rosenthal, H., 1975. Combined effects of cadmium and salinity on development and survival of garpike eggs. Helgoländer wiss. Meeresunters. 27, 268-282.

Windom, H., Sticknex, R., Smith, R., White, D. \& TAylor, F., 1973. Arsenic, cadmium, copper, mercury and zinc in some species of North Atlantic finfish. J. Fish. Res. Bd Can. 30, 275-279.

WoN, J. H., 1973. The concentrations of mercury, cadmium, lead and copper in fish and shelfish of Korea. Bull. Korean Fish. Soc. 6, 1-19.

First author's address: Dr. V. Dethlefsen

Institut für Küsten- und Binnenfischerei

D - 219 Cuxhaven

Kapitän-Alexander-Str. 54

Federal Republic of Germany 